\title{
CORPORATE SOCIAL RESPONSIBILITY TERHADAP CUSTOMER LOYALTY YANG DIMEDIASI OLEH ELECTRONIC SERVICE QUALITY, TRUST DAN CUSTOMER SATISFACTION PADA INDUSTRI PERBANKAN INDONESIA
}

\author{
Delia Anindita Prashella* \\ Universitas Trisakti, Indonesia \\ Kurniawati \\ Universitas Trisakti, Indonesia \\ Herfin Fachri \\ Universitas Trisakti, Indonesia \\ Prita Karina Diandra \\ Universitas Trisakti, Indonesia \\ Taryono Aji \\ Universitas Trisakti, Indonesia
}

\begin{abstract}
This article examines the effect of Corporate Social Responsibility (CSR) programs on customer loyalty that is mediated by service quality, trust and electorinic customer satisfaction. Using a sample of 207 BUKU 4 bank customers in Indonesia who have accounts for more than six months. The survey was conducted by filling out an online questionnaire. Data analysis used Structural Equation Modeling (SEM). The results obtained from this study indicate that CSR mediated by electronic service quality, trust, and customer satisfaction overall has a positive influence on customer loyalty of banks in Indonesia. This study reveals that the bank is not only oriented towards business profit, but also carry out CSR programs in a sustainable manner. The CSR program is considered important, because it can build effective communication with customers and prospective customers. It can also increase customer awareness. In addition, currently the technology owned by the bank will be a factor that can build consumer loyalty.
\end{abstract}

JEL: M30, M31, M39

Keywords : Corporate social responsibility (CSR), customer satisfaction, electronic-service quality, trust, customer loyalty.

\begin{abstract}
ABSTRAK
Artikel ini menguji pengaruh program Corporate Social Responsibility (CSR) terhadap loyalitas pelanggan yang dimediasi oleh kualitas layanan, kepercayaan dan kepuasan pelanggan elektronik. Menggunakan sampel 207 nasabah bank BUKU 4 di Indonesia yang memiliki rekening lebih dari enam bulan. Survei dilakukan dengan mengisi kuesioner online. Analisis data menggunakan Structural Equation Modelling (SEM). Hasil yang diperoleh dari penelitian ini menunjukkan bahwa CSR yang dimediasi oleh electronic service quality, trust, dan customer satisfaction secara keseluruhan berpengaruh positif terhadap loyalitas nasabah bank-bank di Indonesia. Studi ini mengungkapkan bahwa bank tidak hanya berorientasi pada keuntungan bisnis, tetapi juga menjalankan program CSR secara berkelanjutan. Program CSR dinilai penting, karena dapat membangun komunikasi yang efektif dengan pelanggan dan calon pelanggan. Hal ini juga dapat meningkatkan kesadaran pelanggan. Selain itu, saat ini teknologi yang dimiliki bank akan menjadi faktor yang dapat membangun loyalitas konsumen.
\end{abstract}

Kata Kunci : Corporate Social Responsibility (CSR), customer satisfaction, electronic-service quality, trust, customer loyalty.

\footnotetext{
${ }^{*}$ Email : aprashella@gmail.com

Received : 05-02-2021, Accepted : 21-08-2021, Published : 29-08-2021

P-ISSN : 2087-9954, E-ISSN : 2550-0066. DOI : http: http://dx.doi.org/10.26418/jebik.v10i2.44779
} 


\section{PENDAHULUAN}

Bank sebagai badan usaha yang bertugas mengumpulkan, mendistribusikan dana berbentuk kredit serta pemberian jasa finansial lainnya yang memiliki tujuan meningkatkan taraf hidup serta hajat hidup orang banyak/masyarakat. Dengan peran penting tersebut, kesehatan perbankan menjadi hal yang sangat diperhatikan. Agar selalu terjaga kesehatannya, aturan mengenai modal inti bank dalam kegiatan usaha dan jaringan kantor telah dibuat. Komitmen pemegang saham tentang kelangsungan bank secara individu maupun industri bisa dilihat dari besarnya modal inti yang ada (Nisa, 2018). Otoritas Jasa Keuangan (OJK) sebagai regulator perbankan, mengatur bank berdasarkan kegiatan usahanya. OJK juga selalu memotivasi bank agar bisa meningkatkan modal inti yang dimiliki. Di Peraturan Otoritas Jasa Keuangan (POJK) terdapat empat kelompok bank yang diklasifikasikan menurut modal inti bank. BUKU (Bank Umum Berdasarkan Kegiatan Usaha) dijelaskan menjadi BUKU 1, modal inti yang dimiliki oleh bank adalah kurang dari Rp1 Triliun, BUKU 2 modal inti yang dimiliki bank adalah Rp 1 Triliun sd kurang dari Rp5 Triliun, BUKU 3 modal inti yang dimiliki oleh bank Rp5 Triliun sd kurang dari Rp30 Triliun, dan BUKU 4 modal inti yang dimiliki bank adalah sama atau lebih dari Rp. 30 Triliun (Nasution,Siregar \& Novianti, 2020). Sejak tahun 2019, dua bank berhasil masuk kategori BUKU 4 yaitu Bank Danamon dan Bank Panin. Sehingga total bank BUKU 4 yang terdaftar adalah seperti tabel di bawah ini:

Tabel 1. Kategori Bank Buku 4

\begin{tabular}{ll}
\hline \multicolumn{1}{c}{ Bank Buku 4 } & \multicolumn{1}{c}{ Modal Inti } \\
\hline Bank Rakyat Indonesia (BRI) & Rp159 triliun (2017) \\
Bank Negara Indonesia (BNI) & Rp139,35 triliun \\
Bank Mandiri & Rp179,16 triliun \\
Bank Central Asia (BCA) & Rp148,7 triliun \\
CIMB Niaga & Rp40,2 triliun \\
Bank Panin & Rp35,51 triliun \\
Bank Danamon & Rp32,18 triliun \\
\hline
\end{tabular}

Sumber: Nurul, (2021)

Berdasarkan Tabel 1, terdapat tujuh bank umum/konvensional yang telah masuk dalam kategori bank BUKU 4, yang berarti ketujuh bank ini memiliki modal inti terbesar di Indonesia. Dari modal intinya, bank BUKU 4 ini memiliki kantor cabang yang jumlahnya banyak dan tersebar, sumber daya serta teknologi yang mumpuni, lebih baik dan memadai untuk memberikan pelayanan pada nasabahnya (Sari \& Widaninggar, 2018). Dalam memberikan pelayanan pada nasabahnya, perbankan menyediakan electronic service quality serta menyumbang kontribusi bisnisnya pada masyarakat dengan aktivitas Corporate Social Responsibility (CSR) (Faqihudin, 2020). Maka pada penelitian sebelumnya, mengungkapkan bahwa kegiatan corporate social responsibility memiliki pengaruh positif terhadap electronic service quality, trust, customer satisfaction dan customer loyalty (Ashraf et al., 2017; Islam et al., 2021; Raza et al., 2020).

Customer loyalty dari nasabah perbankan merupakan salah satu sumber pendapatan dan keunggulan kompetitif industri perbankan. Nasabah dikatakan loyal ketika menunjukkan kesetiaan untuk menggunakan kembali produk dan layanan yang berkelanjutan meski adanya tekanan 
eksternal, seperti kegiatan iklan pemasaran dan pengaruh situasional lainnya (Raza et al., 2020). Dewasa ini, customer loyalty memiliki alokasi dana promosi yang rendah sehingga mempertahankan nasabah yang setia merupakan tantangan bagi bank. Nasabah tidak dapat melihat adanya perbedaan yang mencolok antara bank satu dan lainnya. Maka, strategi pemasaran melalui kegiatan CSR menjadi penting bagi perusahaan jasa untuk mempertahankan dan menumbuhkan basis pelanggannya (Shah \& Khan, 2019). Tanggung jawab sosial perusahaan (CSR) juga menjadi salah satu hal yang dipertimbangkan nasabah dan calon nasabah saat melakukan keputusan pembelian. Melalui kegiatan CSR yang dilakukan bank, bank dapat mencerminkan bahwa kontribusi usahanya memiliki tanggung jawab ke masyarakat (Jeon et al., 2020; Raza et al., 2020). Penelitian sebelumnya mengungkapkan bahwa penerapan corporate social responsibility akan mempengaruhi customer loyalty (Faqihudin, 2020).

Dalam beberapa tahun terakhir, konsep CSR telah menjadi fenomena internasional di semua bidang bisnis. Bisnis perbankan juga merupakan salah satu industri terpenting dalam perekonomian di dunia. Bank selalu berupaya untuk mendapatkan reputasi dan kepercayaannya dari nasabah. Caranya antara lain, dengan menerapkan prinsip tanggung jawab sosial, sehingga perbankan mulai mengadopsi konsep CSR ke dalam strateginya. Dengan tujuan untuk mencapai kinerja ekonomi yang memadai dengan pendekatan sosial dan lingkungan. Perbankan komersial juga melakukan kegiatan tanggung jawab sosial perusahaan dengan prinsip etika (Paulík et al., 2015). Kegiatan CSR mendapat perhatian dan telah diteliti secara ekstensif di berbagai disiplin ilmu selama beberapa dekade terakhir (Farooq \& Salam, 2020). Dari literatur yang tersedia juga memperlihatkan bahwa pelanggan atau nasabah menilai kegiatan CSR perusahaan saat membuat keputusan konsumsi (Shah \& Khan, 2019).

Pada industri perbankan khususnya, sebelum membuat keputusan konsumsi, nasabah memperhitungkan layanan teknologi yang disediakan bank. Layanan teknologi ini akan membuat satu bank dengan yang lainnya akan terus bersaing untuk menarik minat nasabahnya. Persaingan yang ketat tersebut mengharuskan bank untuk meningkatkan electronic service qualitynya. ATM, internet banking, mobile banking adalah salah satu contoh dari layanan teknologi perbankan yang ada (Raza et al., 2020). Perkembangan teknologi yang sangat pesat ini telah mempermudah nasabah untuk dapat menikmati layanan perbankan secara digital. Pesatnya perkembangan dan meningkatnya pengguna internet di Indonesia menjadi salah satu katalis yang membuat berkembang pesatnya layanan digital/teknologi di industri perbankan. Dewasa ini, penggunaan internet di banyak negara terus meningkat. Pada Q1 2020, Indonesia menempati peringkat empat sebagai negara dengan internet user dan internet penetration terbanyak di dunia. Pengguna internet di Indonesia telah mencapat sekitar 171.260.000 pengguna di kawasan Asia (Amin, 2016). Keberhasilan adaptasi digital pada industri bank tidak lepas dari teknologi yang digunakan. Teknologi mendukung terciptanya trust dan satisfied nasabahnya. Penelitian sebelumnya menjelaskan bahwa adanya pengaruh persepsi CSR terhadap electronic service quality yang dirasakan oleh nasabah (Shah \& Khan, 2019).

Dalam dimensi pemasaran, trust pelanggan menjembatani terciptanya hubungan pertukaran sosial. Trust berarti adanya hubungan di mana satu mitra pertukaran (yaitu pelanggan) percaya pada kehandalan dan integritas suatu perusahaan ataupun bank. Penelitian pendahulu menunjukan adanya persepsi trust pada pelanggan yang berhubungan dengan perhatian, kepedulian, loyalitas, kejujuran, dan kepuasan (Glaveli, 2020). 
Variabel customer satisfaction sebagai mediator menjadi tambahan terbaru dari hasil penelitian sebelumnya (Ashraf et al., 2017; Smith, 2020). Tak ayal, banyak praktik customer satisfaction ditemukan pada banyak perusahaan, karena praktik ini memberikan hubungan yang konkret keuntungan pada masa depan (Smith, 2020). Ada konsep yang muncul di antara para manajer, bahwa customer satisfaction harus menjadi bagian penting dari bisnis perusahaan. Customer satisfaction juga dipandang sebagai indikator kunci dan kondisi yang diperlukan untuk keuntungan yang berkelanjutan. Namun, customer satisfaction bukanlah tujuan pemasaran yang cukup untuk mendorong profitabilitas. Baiknya, perusahaan juga menargetkan customer loyalty yang membuahkan hasil akhir berupa customer satisfaction. Hal ini juga merupakan sebagai langkah lain menuju profitabilitas. Dalam bisnis perbankan, customer satisfaction diperlukan untuk mempertahankan dan membuat nasabah tetap menggunakan jasa perbankan. Hasil penelitian sebelumnya mengungkapkan bahwa terdapat peran mediasi customer satisfaction antara CSR dengan customer loyalty (Ashraf et al., 2017).

Penelitian kali ini akan meneliti tentang pengaruh corporate social responsibility, electronic service quality, trust dan customer satisfaction terhadap customer loyalty pada nasabah bank yang termasuk kategori bank BUKU 4. Diharapkan perusahaan perbankan di Indonesia mampu meningkatkan kualitas dari teknologi mereka. Oleh karena itu, rumusan masalah dalam penelitian ini, apakah variabel corporate social responsibility, customer loyalty, electronic service quality, trust dan customer satisfaction saling memiliki pengaruh dan dengan adanya peran variabel mediasi?

\section{TINJAUAN LITERATUR}

\subsection{Corporate Social Responsibility (CSR)}

Praktik CSR telah menjadi suatu kewajiban bagi perusahaan. CSR berperan penting karena menghasilkan peningkatan kinerja organisasi, nilai yang dirasakan pelanggan dan keunggulan kompetitif (Raza et al., 2020). Menurut saran dari stakeholder theory, keputusan manajemen tidak hanya bertumpu pada kepentingan pemegang saham. Keputusan manajemen juga harus memikirkan pelanggan sebagai stakeholder yang terpengaruh atas keputusan perusahaan (Pérez \& del Bosque, 2015). CSR sering dianggap sebagai sarana yang tepat untuk membangun budaya nilai-nilai kebersamaan dengan berbagai pemangku kepentingan, misalnya karyawan, pemasok, pelanggan, dan seluruh komunitas pada umumnya (Farooq \& Salam, 2020). Telah banyak praktik CSR yang diteliti dari berbagai macam konteks. Salah satunya memaparkan bahwa inisiatif CSR berpengaruh signifikan terhadap peran dan perilaku ekstra pelanggan dalam konteks kinerja keuangan dan non keuangan (Prieto et al., 2020).

\section{2. Electronic Service Quality $(E-S Q)$}

Tidak ada interaksi antar manusia yang terjadi di dalam E-SQ. Sehingga pelanggan dapat dengan sendirinya menggunakan internet untuk melakukan tindakan tertentu. Teknologi unmanned, termasuk ATM, perbankan berbasis situs internet dan berbagai aplikasi pada ponsel adalah contoh E-SQ (Raza et al., 2020). Pada saat ini, semua bank menawarkan layanan e-banking, strategi dasar untuk mendapatkan keunggulan kompetitif adalah memberikan kualitas unggul dalam platform penyampaian layanan ini. Layanan digital dan elektronik ini menghemat waktu dan biaya nasabah perbankan (Shankar \& Jebarajakirthy, 2019). Terjadi perkembangan teknologi yang sangat signifikan dalam industri perjalanan dan pariwisata. Peningkatan pesat ini dikarenakan 
sektor pariwisata mendapatkan interaksi besar-besaran akibat penggunaan internet. E-SQ merupakan faktor penting untuk mempertahankan keunggulan kompetitif dan mendapatkan keuntungan jangka panjang selain untuk menarik pelanggan potensial (Rahahleh et al., 2020).

\subsection{Trust}

Trust merupakan kepercayaan pada keahlian serta integritas mitra bisnis yang berkaitan dengan kualitas positif lainnya, seperti kompetensi merek, kejujuran, keadilan, kebajikan, konsistensi, dan tanggung jawab. Trust adalah perilaku yang secara etis tepat dan merupakan komponen penting antara individu dan organisasi (Raza et al., 2020). Perilaku yang bertanggung jawab secara sosial terkait dengan kebajikan, kebaikan, semangat, akan membantu menumbuhkan trust pada pelanggan. Kemudian trust meningkatkan hubungan yang menguntungkan pelanggan dengan perusahaan yang dapat berkembang sebagai hasil dari keyakinan kuat bahwa perusahaan dapat diandalkan, jujur, dan baik hati (Park et al., 2014). Trust merupakan suatu syarat yang wajib ada dalam hubungan jangka panjang antara pelanggan dan perusahaan dalam relationshipcommitment theory. Trust pada industri perhotelkan mencerminkan bahwa hotel tersebut kompeten dan terpercaya. Trust ini akan sangat mempengaruhi loyalitas yang membuat pelanggan ingin berkunjung kembali (Mariño-Romero et al., 2020).

\subsection{Customer satisfaction}

Banyak perusahaan akan menargetkan customer satisfaction. Karena customer satisfaction memberikan jalan konkret menuju profitabilitas perusahaan pada masa depan. Ini berarti ada konsep yang muncul di antara para manajer bahwa customer satisfaction harus menjadi bagian penting dari bisnis (Smith, 2020). Customer satisfaction digambarkan sebagai memuaskan keinginan seseorang atau memenuhi kriteria seseorang atau kita dapat mengatakan bahwa pelanggan yang senang dan puas memiliki perasaan terhadap suatu produk atau layanan yang telah digunakannya (Rasheed et al., 2015). Peranan kepuasan konsumen sangat penting dalam keberlangsungan perusahaan. Hal ini telah menjadi hal krusial untuk perusahaan dan organisasi dalam upaya meningkatkan kualitas produk dan layanan serta mempertahankan loyalitas pelanggan dalam pasar yang sangat kompetitif (Nguyen et al., 2020). Kepuasan dapat diartikan sebagai tindakan penilaian konsumen tarhadap produk atau layanan yang digunakan terhadap tingkat pemenuhannya. Spektrum penilaian ini, termasuk tingkat pemenuhan yang kurang (tidak puas) atau lebih (sangat puas) (Safi \& Alagha, 2020).

\subsection{Customer loyalty}

Customer loyalty mencakup niat pelanggan untuk membeli kembali dan persepsi positif terkait perusahaan. Hal ini pula akan memicu kemauan pelanggan untuk merekomendasikan perusahaan kepada orang lain (Raza et al., 2020). Customer loyalty menjadi perhatian dalam perbankan bagi para profesional karena persaingan yang ketat dan harapan customer yang lebih tinggi. Customer loyalty dipandang sebagai koneksi utama dan keinginan menuju pencapaian, manfaat dan pelaksanaan bisnis (Rasheed et al., 2015). Brand trust, menunjukan seberapa percaya pelanggan terhadap sebuah merek (bank) tersebut dapat diandalkan dan menjaga minat pelanggan. Hal ini berkaitan erat dengan metrik perilaku pelanggan termasuk niat membeli dan loyalitas (Osakwe \& Yusuf, 2020). Customer loyalty bisa berupa sikap permanen serta signifikan terhadap apa pun kepada hal yang dapat berupa merek, layanan, atau produk. Terdapat perbedaan mencolok antara loyalitas dan komitmen. Komitmen merupakan rasa moticasi dan sikat tertentu terhadap 
suatu hubungan sedangkan loyalitas merupakan seperangkat faktor perilaku yang rumit dan kompleks (Sanaullah, 2018).

Berdasarkan uraian tinjauan literatur diatas, dapat dilihat bahwa penelitian ini membantu memahami corporate social responsibility pada industri perbankan di Indonesia yang didukung oleh peran electronic service quality, trust serta customer satisfaction yang dialami oleh nasabah perbankan di Indonesia. Berikut disajikan pada Gambar 1 untuk model pada penelitian ini dan paparkan melalui pengembangan hipotesis di bawah ini :

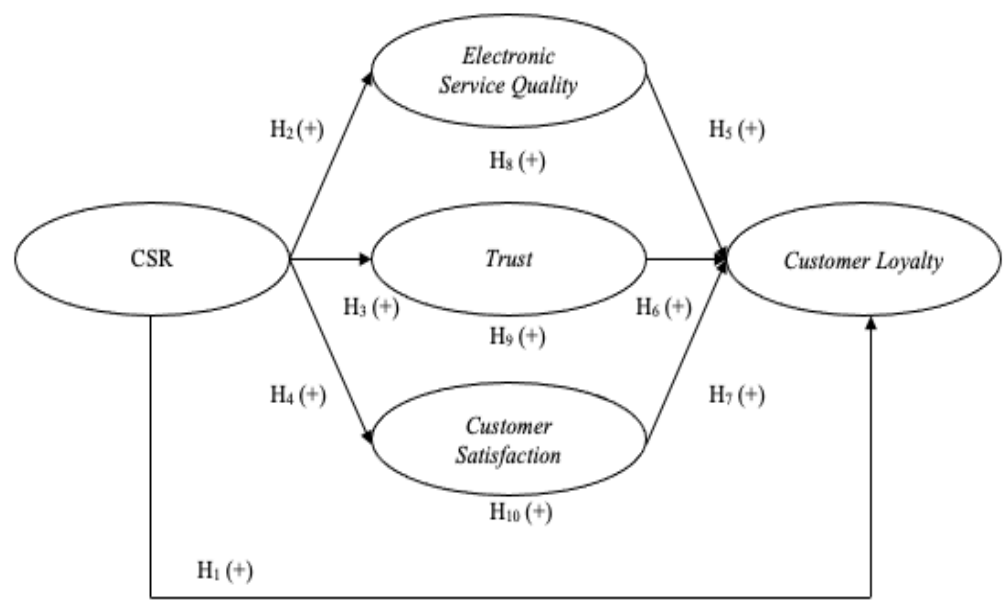

Gambar 1. Model Penelitian

CSR dapat meningkatkan kepuasan yang mengarah pada loyallitas dan pengembalian brand positioning serta dapat meningkatkan pemahaman manajer tentang pentingnya CSR. Berdasarkan hal tersebut, terdapat kesimpulan bahwa CSR memberikan pengaruh positif ke customer loyalty (Akbari et al., 2019). Penelitian sebelumnya mengungkapkan tidak adanya pengaruh CSR terhadap customer loyalty yang disebabkan karena keraguan nasabah akan secara otomatis akan memperhatikan CSR pada saat membuat keputusan pengeluaran dan konsumsi (Raza et al., 2020). Dengan adanya aktivitas CSR perusahaan maka nasabah dapat mengetahui manfaat serta impact bisnis bank ke masyarakat. Melalui hal ini, loyalitas masyarakat terhadap produk perusahaan akan semakin baik. Sehingga dapat dikatakan bahwa kegiatan CSR bank dapat meningkatkan loyalitas dari nasabah (Sari, 2018). Hasil penelitian tersebut CSR berpengaruh signifikan positif terhadap loyalitas nasabah. Sehingga hipotesis pertama dinyatakan sebagai berikut :

\section{$\mathrm{H}_{1}$ : Corporate social responsibility memiliki pengaruh positif kepada customer loyaty.}

Praktik Corporate Social Responsibility memberikan beberapa informasi tambahan berupa atribut yang tidak dapat diobservasi tentang kualitas layanan. Hal yang dimaksud dalam hal ini adalah electronic service quality kepada pemangku kepentingan utamanya, yaitu pelanggan. Aktivitas CSR suatu perusahaan merupakan alat pengukur penting efektivitas organisasi dalam hal layanannya (Raza et al., 2020). Persepsi dan perilaku dalam lingkungan tertentu merupakan keadaan emosional yang diciptakan oleh lingkungan. Lingkungan yang dimaksud sangat mempengaruhi emosi. Emosi yang timbul dari nasabah terhadap layanan adalah perdiktor utama untuk mengevaluasi kualitas layanan (Chairy, 2019). Berdasarkan penelitian yang dilakukan, dapat diketahui bahwa service environment memiliki pengaruh positif namun tidak memiliki signifikansi yang rendah terhadap service quality. Sebaliknya, hasil penelitian lainnya mengungkapkan bahwa 
CSR tidak perpengaruh terhadap Islamic banking service quality (Suminto \& Maharani, 2020).Hal tersebut dapat menerangkan bahwa corporate social responsibility memiliki pengaruh positif langsung kepada electronic service quality. Sehingga hipotesis dinyatakan sebagai berikut :

\section{$\mathrm{H}_{2}$ : Corporate social responsibility berpengaruh positif terhadap Electronic Service Quality.}

Aktivitas corporate social responsibility atau tanggung jawab sosial perusahaan terhadap pelanggan mencakup tindakan sukarela dari perusahaan yang mendukung kesejahteraan pelanggannya (misalnya kualitas produk, integritas atau keandalan, pemahaman kebutuhan pelanggan, dan minat yang tulus). Kegiatan CSR terhadap karyawan dan masyarakat atau lingkungan cenderung merangsang hubungan pertukaran sosial antara organisasi dan pelanggannya. Dalam riset hubungan pemasaran, hubungan pertukaran sosial telah direalisasikan melalui kepercayaan pelanggan (Glaveli, 2020). Dengan adanya kontribusi CSR terhadap produk dan loyalitas pelanggan hotel, menimbulkan efek langsung yang signifikan terhadap kepercayaan pelanggan. Hal ini menciptakan CSR memiliki pengaruh positif terhadap kepercayaan. Trust sebagai kunci bagi kinerja perusahaan karena membantu dalam pengembangan dan pemeliharaan internal bagi perusahaan yang memungkinkan adanya kerjasama antara anggota perusahaan dengan masyarakat di luar perusahaan (Setiantono et al, 2020). Melalui penelitian tersebut dapat diketahui bahwa CSR memiliki pengaruh kepada trust. Berdasarkan hal tersebut, dapat dilihat bahwa CSR memiliki pengaruh positif dengan signifikansi tinggi terhadap trust. Dengan adanya tanggung jawab sosial untuk tujuan tertentu demi kemajuan masyarakat menghasilkan rasa kepercayaan konsumen yang menjadi peran penting dalam penerapannya (Park et al., 2014). Hasil penelitian menyatakan adanya efek dari CSR terhadap kepercayaan. Hipotesis dinyatakan seperti berikut :

\section{H3: Corporate Social Responsibility memiliki pengaruh positif kepada Trust.}

Riset sebelumnya membuktikan secara empiris bahwa kepuasan pelanggan di industri telekomunikasi dipengaruhi oleh praktik corporate social responsibility (CSR) (Islam et al., 2021). Berdasarkan stakeholder theory serta pandangan yang berdasarkan data, bahwa untuk dapat membuat pelanggan menjadi loyal, perusahaan harus dapat memuaskan pelanggan dengan strategi yang tepat. Salah satunya adalah dengan praktik corporate social responsibility (CSR). Penelitian terdahulu mengungkapkan bahwa CSR dapat mempengaruhi customer satisfaction (Akbari et al., 2019). CSR yang difokuskan di bank komersial Republik Ceko atas pengaruhnya yang dilihat dari loyalitas dan kepuasan nasabah dan karyawan bank. Hasil yang didapat menyatakan bahwa kepuasan nasabah merupakan faktor krusial bagi kinerja bank dan aset fundamentalnya (Paulík et al., 2015). Hal ini menjadi bukti bahwa CSR memiliki pengaruh terhadap kepuasan pelanggan. Hal lain juga yang dapat diketahui adalah terdapat hasil bahwa corporate social responsibility memiliki pengaruh positif dengan signifikansi tinggi terhadap customer satisfaction. Hipotesis dinyatakan seperti berikut :

\section{H4: Corporate Social Responsibility memiliki pengaruh positif terhadap Customer Satisfaction.}

Electronic service quality dianggap mempunyai peranan penting dan adalah sebuah fasilitas yang interaktif serta sangat penting diberbagai budaya, karena layanan ini telah menjadi dasar cara pandang nasabah terhadap perbankan dapat memberikan layanannya secara online kepada nasabah dan ini menjadi salah satu cara untuk melihat bagaimana interaksi dan cara 
berperilaku antar perbankan dan nasabah secara elektronik dengan layanan online (Raza et al., 2020). Berdasarkan hal tersebut, terdapat hasil bahwa electronic service quality memiliki pengaruh yang positif signifikan terhadap customer loyalty. Terdapat hasil penelitian yang berbeda, dimana electronic service quality tidak memiliki pengaruh terhadap customer loyalty terhadap pengguna go-pay di Indonesia (Berliana \& Zulestiana, 2020). Ketika layanan online dilakukan dengan baik dan lancar akan membangun kepercayaan dan keyakinan kepada pelanggan serta loyalitas pelanggan juga dapat menunjukkan komitmen secara mendalam untuk kembali berlangganan atau melakukan transaksi kembali melalui website pada masa yang akan datang, apabila harga yang ditawarkan tinggi atau faktor lainnya (Jonathan, 2013). Hasil penelitian tersebut menghasilkan bahwa electronic service quality berpengaruh terhadap customer loyalty. Hipotesis dinyatakan sebagai berikut:

\section{H5: Electronic service quality memiliki pengaruh positif terhadap customer loyalty.}

Penyedia e-banking harus memperhatikan hubungan kepercayaan kepada nasabah dengan jujur, tulus dan menjaga janji perusahaan kepada nasabah. Dalam penelitian ini menghasilkan bahwa e-trust berpengaruh signifikan terhadap e-customer loyalty. Dengan demikian, pengalaman yang tidak terlupakan berdasarkan kualitas produk / layanan secara positif membangun kepuasan dan kepercayaan konsumen yang mengarah pada peningkatan loyalitas pelanggan dalam konteks bisnis-ke-pelanggan (Prisanti et al., 2017). Trust adalah hubungan yang mengikat pelanggan untuk tetap berkomitmen dengan organisasi. Kepercayaan pelanggan adalah alasan untuk pembentukan dan pemeliharaan hubungan jangka panjang antara pelanggan dan asosiasi. Berdasarkan hal tersebut, terdapat hasil bahwa trust memiliki pengaruh yang positif signifikan terhadap customer loyalty (Ashraf et al., 2017). Pertukaran bisnis antara dua pihak atau lebih, bisa terjadi jika pihakpihak tersebut saling percaya. Kepercayaan dianggap sebagai pendorong dalam setiap transaksi yang terjadi antara pembeli dan penjual (Rasheed et al., 2015). Dengan adanya hal ini kepercayaan menciptakan pengaruh positif terhadap loyalitas pelanggan. Hipotesis dinyatakan sebagai berikut:

\section{H6: Trust berpengaruh positif terhadap customer loyalty.}

Kualitas layanan adalah faktor utama kepuasan pelanggan dan itu adalah prediktor customer loyalty. Customer satisfaction merupakan langkah awal untuk membangun customer loyalty yang menghasilkan hubungan jangka panjang dan meningkatkan citra perusahaan. Perusahaan yang dapat mengetahui kebutuhan pelanggan untuk memuaskan mereka, mendapatkan lebih banyak keuntungan dibandingkan dengan perusahaan-perusahaan, yang tidak melakukan praktik serupa (Aksar et al., 2019). Customer satisfaction memiliki pengaruh positif terhadap customer loyalty di sebagian besar jenis bisnis (Smith, 2020). Customer satisfaction atau kepuasan nasabah memiliki tujuan utama yang ingin dicapai perusahaan, hal tersebut karena dengan adanya kepuasan yang dirasakan oleh pelanggan dan memberikan dampak jangka panjang (Faqihudin, 2020). Dalam hal ini kepuasan nasabah menciptakan pengaruh positif terhadap loyalitas nasabah. Hipotesis dinyatakan sebagai berikut:

\section{H7: Customer Satisfaction memiliki pengaruh positif kepada customer loyalty.}

Jika bank terlibat dalam perilaku bertanggung jawab secara sosial, maka nasabah akan secara positif mengevaluasi kualitas layanan secara keseluruhan. Ketika pelanggan memiliki persepsi positif terhadap E-SQ, maka evaluasi layanan elektronik ini berdampak positif terhadap customer loyalty (Shankar \& Jebarajakirthy, 2019). Penelitian sebelumnya menegaskan bahwa ESQ adalah preseden customer loyalty di sektor perbankan. E-SQ juga berperan sebagai mediator 
antara CSR dan customer loyalty (Raza et al., 2020). Program CSR suatu bentuk kepedulian perushaan terhadap lingkungannya, CSR dalam pandangan islam yaitu termasuk konsekuensi inhern dari ajaran isalm itu sendiri dimana dengan adanya kualitas pelayanan sebagai konsekuensi yang perlu diperhatikan oleh Islamic banks terhadap pentingnya perkembangan lingkungan perbankan yang cepat (Suminto \& Maharani, 2020) dalam penelitian ini menghasilkan bahwa CSR tidak memiliki pengaruh terhadap loyalitas nasabah namun Islamic banking service quality mempunyai pengaruh terhadap loyalitas nasabah.Hipotesis dinyatakan sebagai berikut :

\section{Hs: Terdapat pengaruh corporate social responsibility kepada customer loyalty dengan electronic service quality sebagai mediator.}

CSR yang digerakkan oleh laba perusahaan dapat merusak reputasi perusahaan yang menegaskan bahwa untuk mencapai customer loyalty dan reputasi yang baik, perusahaan harus mendapatkan trust pelanggan melalui kompetensi, kebajikan, yaitu kepedulian yang tulus terhadap keberlanjutan. Banyak studi yang menegaskan peran trust sebagai mediator. Di sektor perbankan Pakistan, peran mediasi trust antara CSR dan customer loyalty dan dari word of mouth (Raza et al., 2020). Tanggung jawab sosial serta kualitas layanan perusahaan jika dikembangkan akan menimbulkan kesan positif pada produk perusahaan dengan adanya kepercayaan pelanggan yang akan terbentuk maka akan mendorong pengguna produk untuk melakukan e-WOM kepada orang lain (Rastini \& Nurcaya, 2019). Berdasarkan penelitian tersebut menghasilkan bahwa terdapat pengaruh yang signifikan antara trust in e-WOM aktivitas nasabah PT Bank X secara signifikan memediasi pengaruh kualitas pelayanan dan CSR terhadap aktivitas $e$-WOM nasabah PT Bank X. Kegiatan CSR terhadap karyawan dan masyarakat atau lingkungan cenderung merangsang hubungan pertukaran sosial antara organisasi dan pelanggan dalam hal ini hubungan pertukaran sosial telah dioperasionalkan melalui kepercayaan pelanggan (Glaveli, 2020) dalam hal ini hasil penelitian menyatakan bahwa CSR untuk menuju loyalitas pelanggan dalam membangun hubungan jangka panjang didapatkan dari kepercayaan pelanggan. Hipotesis dinyatakan sebagai berikut :

\section{H9: Terdapat pengaruh corporate social responsibility kepada customer loyalty dengan trust sebagai mediator.}

Customer satisfaction dan customer loyalty merupakan indikator penting dari orientasi pasar di sektor publik yang mempengaruhi kinerja pemerintah. Pelanggan akan puas ketika produk dan layanan yang ditawarkan oleh perusahaan yang menerapkan CSR. Penelitian sebelumnya mengungkapkan tidak hanya hubungan langsung antara CSR dan customer satisfaction, tetapi juga bahwa customer satisfaction sepenuhnya menengahi hubungan antara CSR dan nilai pasar perusahaan. Dengan demikian, pengaruh CSR yang diharapkan terhadap loyalitas pelanggan mungkin tidak langsung melalui kepuasan pelanggan (Lee \& Shin, 2018). Penelian sebelumnya juga mengungkapkan bahwa customer satisfaction memediasi pengaruh antara CSR terhadap customer loyalty secara signifikan (Akbari et al., 2019). Perusahaan bus antarkota perlu menangani masalah CSR dan loyalitas pelanggan untuk memasatikan pembangunan jangka panjang dan operasi keberlanjutannya dimana dalam hal ini melibatkan adanya peran dari kepuasan pelanggan (Chang \& Yeh, 2017) dengan hasil penelitian CSR membantu memperkuat loyalitas pelanggan perusahaan bus antarkota melalui efek mediasi kepuasan pelanggan. Hipotesis dinyatakan sebagai berikut:

$\mathrm{H}_{10}$ : Terdapat pengaruh corporate social responsibility kepada customer loyalty dengan customer satisfaction sebagai mediator. 


\section{METODE PENELITIAN}

Penelitian yang menjadi variabel penelitian dari responden corporate social responsibility (CSR), kemudian variabel electronic service quality, trust, customer satisfaction serta customer loyalty. Penelitian ini dilakukan untuk menguji hipotesis untuk menganalisis pengaruh dari masing-masing variabel menggunakan Structural Equation models (SEM). Time horizone pada penelitian ini yaitu dengan cara Cross-Sectional karena pengambilan sampel dibatasi waktu yang ditentukan (Sekaran \& Bougie, 2016). Penelitian ini menggunakan beberapa variabel dan pengukurannya, yaitu corporate social responsibility (CSR) yang diukur dengan 11 item pernyataan, electronic service quality dengan 8 item pernyataan, trust dengan 3 item pernyataan, customer satisfaction dengan 10 item pernyataan dan customer loyalty dengan 6 item pernyataan yang masing-masing menggunakan tata cara metode kuesioner 5 skala likert.

Populasinya adalah masyarakat yang berumur minimal 17 tahun di Indonesia. Jumlah anggota populasi tidak diketahui secara jelas sehingga penelitian ini mengambil sampel. Pengambilan sampel penelitian ini menggunakan metode non probabilitas sampling dengan teknik purposive sampling. Kriteria yang diinginkan adalah hanya kepada nasabah yang memiliki rekening dari salah satu bank yang sudah BUKU 4, nasabah yang telah memiliki rekening dibank tersebut minimal enam bulan, nasabah mengetahui kegiatan CSR / tanggung jawab sosial perusahaan serta nasabah pernah mengakses layanan elektronik perbankan (mbanking, sms banking, ATM, website bank). Kuesioner disebarkan secara online dengan menggunakan google form kepada 273 responden yang tersebar di lima pulau besar di Indonesia, yaitu Sumatera, Jawa, Kalimantan, Sulawesi, dan Papua. Jumlah hasil responden yang diterima sebanyak 210 responden dengan 3 responden tidak bisa digunakan karena responden tersebut tidak termasuk ke dalam kriteria pengisian. Sehingga jumlah responden yang digunakan dalam penelitian ini ada 207 responden $(76 \%)$.

\section{HASIL DAN PEMBAHASAN}

Profil responden disajikan pada Tabel 2, dengan klasifikasi jenis kelamin, usia, pendidikan, pekerjaan, pendapatan per bulan, dan jangka waktu menggunakan jasa perbankan. Berdasarkan jenis kelamin, mayoritas responden adalah laki-laki yang terdiri dari 105 responden atau $50.7 \%$ dari total responden. Berdasarkan pekerjaan, mayoritas responden bekerja sebagai karyawan yang terdiri dari 166 responden atau $80.2 \%$ dari responden. Berdasarkan usia, mayoritas responden berusia antara 23-28 tahun terdiri dari 74 responden atau $35.7 \%$ dari total responden. Berdasarkan tingkat pendidikan, mayoritas responden berpendidikan sarjana $(\mathrm{S} 1, \mathrm{~S} 2, \mathrm{~S} 3)$ yang terdiri dari 172 responden atau $83.1 \%$ dari total responden. Berdasarkan jangka waktu penggunaan, mayoritas responden telah menggunakan layanan perbankan lebih dari enam bulan terdiri dari 207 responden atau $100 \%$ responden. 
Tabel 2. Tabel Profil Responden

\begin{tabular}{|c|c|c|}
\hline Profil Responden & Jumlah & $\%$ \\
\hline \multicolumn{3}{|l|}{ 1. Jenis Kelamin } \\
\hline Pria & 105 & 50.7 \\
\hline Wanita & 102 & 49.3 \\
\hline Total & 207 & 100 \\
\hline \multicolumn{3}{|l|}{ 2. Usia } \\
\hline $17-22$ tahun & 39 & 18.8 \\
\hline $23-28$ tahun & 74 & 35.7 \\
\hline 29 - 34 tahun & 34 & 16.4 \\
\hline 34 tahun > & 60 & 29 \\
\hline Total & 207 & 100 \\
\hline \multicolumn{3}{|l|}{ 3. Pendidikan } \\
\hline SMA dan sederajat & 7 & 3.4 \\
\hline Diploma dan sederajat & 28 & 13.5 \\
\hline Sarjana $\mathrm{S} 1 / \mathrm{S} 2 / \mathrm{S} 3$ & 172 & 83.1 \\
\hline Total & 207 & 100 \\
\hline \multicolumn{3}{|l|}{ 4. Pekerjaan } \\
\hline Pelajar/Mahasiswa & 21 & 10.1 \\
\hline Karyawan & 166 & 80.2 \\
\hline Wiraswasta & 20 & 9.7 \\
\hline Total & 207 & 100 \\
\hline \multicolumn{3}{|l|}{ 5. Pendapatan per bulan } \\
\hline$\leq 4.000 .000$ & 40 & 19.3 \\
\hline $4.000 .001-8.000 .000$ & 91 & 44 \\
\hline$\geq 8.000 .001$ & 76 & 36.7 \\
\hline Total & 207 & 100 \\
\hline \multicolumn{3}{|c|}{ 6. Jangka Waktu Menggunakan Jasa Perbankan } \\
\hline$>6$ bulan & 207 & 100 \\
\hline
\end{tabular}

Kemudian, frekuensi dan intensitas disajikan pada Tabel 3, dengan klasifikasi layanan perbankan yang sering digunakan, layanan elektronik perbankan apa yang paling sering digunakan, dan Jenis CSR/tanggung jawab sosial perusahaan perbankan mana yang Anda ketahui. Berdasarkan layanan perbankan yang paling sering digunakan, mayoritas responden menggunakan layanan perbankan dari bank Mandiri yang terdiri dari 77 responden atau 37.2\% dari total responden. Berdasarkan layanan elektronik perbankan yang paling sering digunakan, mayoritas responden menggunakan layanan elektronik M-Banking yang terdiri dari 154 responden atau 74.4\% dari total responden. Berdasarkan jenis CSR perbankan yang diketahui, mayoritas responden mengetahui CSR tentang Pendidikan dan dunia Pendidikan yang terdiri dari 100 responden atau $48.3 \%$ dari total responden. Pada Tabel 2, berdasarkan layanan perbankan yang paling sering digunakan, minoritas responden menggunakan layanan perbankan dari Bank Danamon yang terdiri dari 1 responden atau $0.5 \%$ dari total responden. Berdasarkan layanan elektronik perbankan yang paling sering digunakan, minoritas responden menggunakan layanan elektronik SMS Banking yang terdiri dari 7 responden atau 3.4\% dari total responden. Berdasarkan 
jenis CSR perbankan yang diketahui, minoritas responden mengetahui CSR tentang lingkungan hidup yang terdiri dari 18 responden atau $8.7 \%$ dari total responden.

Tabel 3. Tabel Frekuensi dan Intensitas

\begin{tabular}{|c|c|c|c|}
\hline \multicolumn{2}{|c|}{ Frekuensi \& Intensitas } & Jumlah & $\%$ \\
\hline \multicolumn{4}{|c|}{ 1. Layanan perbankan mana yang paling sering Anda gunakan } \\
\hline & BRI & 15 & 7.2 \\
\hline & BCA & 71 & 34.3 \\
\hline & MANDIRI & 77 & 37.2 \\
\hline & BNI & 32 & 15.5 \\
\hline & CIMB NIAGA & 8 & 3.9 \\
\hline & PANIN & 3 & 1.4 \\
\hline & DANAMON & 1 & 0.5 \\
\hline Total & & 207 & 100 \\
\hline \multicolumn{4}{|c|}{ 2. Layanan elektronik perbankan apa yang paling sering Anda gunakan } \\
\hline & M-Banking & 154 & 74.4 \\
\hline & SMS Banking & 7 & 3.4 \\
\hline & ATM & 32 & 15.5 \\
\hline & Website Bank & 14 & 6.8 \\
\hline Total & & 207 & 100 \\
\hline \multicolumn{4}{|c|}{ 3. Jenis CSR/tanggung jawab sosial perusahaan perbankan mana yang Anda ketahui } \\
\hline & Pendidikan dan Dunia Pendidikan & 100 & 48.3 \\
\hline & Edukasi Perbankan & 42 & 20.3 \\
\hline & Sosial Kemasyarakatan & 47 & 22.7 \\
\hline & Lingkungan Hidup & 18 & 8.7 \\
\hline Total & & 207 & 100 \\
\hline
\end{tabular}

Berdasarkan Tabel 4 dapat diketahui bahwa 38 indikator lainnya memiliki nilai signifikansi diatas 0,40 yang artinya ke 38 indikator tersebut di nilai valid. Dengan hal ini maka indikator yang tersisa dapat digunakan untuk analisis lebih lanjut. Hasil uji reliabilitas, seluruh variabel memiliki nilai cronbach's alpha lebih dari 0,6 artinya telah memenuhi kriteria reliabilitas atau terdapat konsistensi internal antara indikator dalam sebuah variabel.

Tabel 4. Uji Validitas, Uji Reliabilitas dan Statistik Deskritif

\begin{tabular}{|c|c|c|c|c|}
\hline & Indikator & Mean (SD) & $\begin{array}{l}\text { Factor } \\
\text { Loading }\end{array}$ & $\begin{array}{l}\text { Cronbach's } \\
\text { Alpha }\end{array}$ \\
\hline \multicolumn{2}{|c|}{ Corporate Social Responsibility (CSR) } & $\begin{array}{c}4.0804 \\
(0.51951)\end{array}$ & & 0.861 \\
\hline 1 . & $\begin{array}{l}\text { Bank ini menetapkan prosedur untuk memenuhi pengaduan } \\
\text { nasabah }\end{array}$ & $\begin{array}{c}4.37 \\
(0.751)\end{array}$ & 0.522 & \\
\hline 2 . & Bank ini memperlakukan nasabahnya dengan jujur & $\begin{array}{c}4.23 \\
(0.783)\end{array}$ & 0.599 & \\
\hline 3 & $\begin{array}{l}\text { Bank ini memiliki pegawai yang menawarkan informasi } \\
\text { lengkap tentang produk perusahaan/layanan kepada } \\
\text { pelanggan. }\end{array}$ & $\begin{array}{c}4.29 \\
(0.734)\end{array}$ & 0.537 & \\
\hline
\end{tabular}


4. Bank ini menggunakan kepuasan nasabah sebagai indikator

4.30

0.652 untuk meningkatkan produk atau layanan pemasaran.

$(0.730)$

5. Bank ini berupaya untuk mengetahui kebutuhan nasabah

6. Bank ini membantu menyelesaikan masalah sosial

3.79

$(0.861)$

7. Bank ini berperan dalam masyarakat di luar pencipataan manfaat ekonomi

(0.806)

8. Bank ini menyumbangkan uang untuk acara budaya dan sosial (misalnya, music atau olahraga)

$3.99 \quad 0.626$

(0.788)

9. Bank ini menggunakan sebagian dari anggarannya untuk sumbangan dan proyek sosial untuk memajukan situasi kelompok masyarakat yang paling tidak beruntung

$3.91 \quad 0.636$

$(0.840)$

10. Bank ini berkepentingan untuk meningkatkan kesejahteraan masyarakat secara umum

11. Bank ini peduli dengan penghormatan dan pelestarian lingkungan alam

\section{Electronic Service Quality}

1. Informasi di m-banking/sms banking/internet 4.43

2. M-banking/sms banking/internet banking/ATM/website bank ini mudah digunakan

3. Bank melindungi informasi tentang perilaku belanja web saya

4. Bank tidak membagikan infromasi pribadi saya

5. M-banking/sms banking/internet banking/ATM/website bank ini selalu tersedia untuk bisnis. bank ini dapat dengan cepat dijalankan

(0.714)

7. Catatan di m-banking/sms banking/internet bankin/ATM/website bank saya selalu akurat

8. M-banking/sms banking/internet banking/ATM/website bank ini memberikan janji yang akurat tentang pemberian layanan 
2. Bank ini jujur dan jujur kepada nasabah

4.25

$(0.663)$

3. Bank ini bisa dipercaya oleh nasabah

Customer Satisfaction

1. Bank ini merupakan penyedia layanan perbankan yang terbaik yang pernah saya gunakan

2. Layanan yang saya terima persis seperti yang saya butuhkan

3. Saya puas dengan keputusan saya untuk menggunakan layanan perbankan ini

4. Pilihan saya untuk menggunakan layanan ini adalah pilihan yang bijaksana

5. Jika saya ingin menggunakan layanan yang lain, saya akan tetap menggunakan layanan dari bank ini

6. Saya sangat menikmati layanan bank ini

7. Saya merasa nyaman dengan keputusan saya menggunakan layanan ini

8. Saya senang dengan menggunakan layanan ini

9. Memiliki layanan ini merupakan pengalaman yang baik

10. Saya yakin menggunakan layanan ini adalah hal yang benar

\section{Customer Loyalty}

1. Saya adalah nasabah setia bank ini

2. Saya berniat untuk tetap menjadi nasabah bank ini

3. Bank ini adalah pilihan pertama saya ketika saya ingin membuka rekening

4. Saya cenderung mengatakan hal-hal positif tentang bank ini

5. Saya akan merekomendasikan bank ini kepada anggota keluarga dan teman saya

6. Saya akan merekomendasikan bank ini jika diminta oleh orang lain
$4.34 \quad 0.804$

$(0.685)$

4.1966

(0.57297)

4.07

$(0.782)$

4.18

(0.747)

4.28

0.768

(0.675)

4.21

0.808

(0.699)

4.13

(0.766)

4.18

(0.739)

0.752

4.27

(0.700)

4.24

(0.717)

4.19

(0.725)

4.21

(0.724)

4.1312

0.833

(0.59762)

4.33

0.729

(0.781)

4.27

(0.719)

4.00

(1.002)

4.11

0.741

(0.745)

4.10

0.819

(0.766)

3.99

0.724

0.932

.814

.708

0.834

0.841

0.799

0.781

0.779

0.681

(0.809) 
Tabel 5. Tabel Uji Goodness of Fit

\begin{tabular}{ccccc}
\hline $\begin{array}{c}\text { Jenis } \\
\text { Pengukuran }\end{array}$ & Pengukuran & Nilai & $\begin{array}{c}\text { Batas penerimaan yang di } \\
\text { sarankan }\end{array}$ & Kesimpulan \\
\hline $\begin{array}{c}\text { Absolute fit } \\
\text { measures }\end{array}$ & $p$ & .000 & $\geq 0,05$ & Poor fit \\
& ECVI & 10.310 & $\begin{array}{c}\text { Mendekati nilai Saturated } \\
\text { dibanding independen }\end{array}$ & $\begin{array}{c}\text { Goodness of fit } \\
\text { Incremental fit }\end{array}$ \\
$\begin{array}{c}\text { measures } \\
\text { RMSEA }\end{array}$ & 0.095 & 0.735 & $\geq 0,90$ atau mendekati 1 & Goodness of fit \\
& IFI & 0.643 & $\geq 0,90$ atau mendekati 1 & Poor fit \\
& TLI & 0.714 & $\geq 0,90$ atau mendekati 1 & Poor fit \\
& CFI & 0.732 & $\geq 0,90$ atau mendekati 1 & Poor fit \\
Parsimonius fit & CMIN/DF & 2.860 & $\geq 0,90$ atau mendekati 1 & Poor fit \\
measure & AIC & 2123.867 & Mendekati nilai Saturated & Goodness of fit \\
& & & dibanding independen & \\
\hline
\end{tabular}

Metode analisa data dalam penelitian ini adalah SEM dengan program AMOS 24. Disimpulkan bahwa syarat utama dari nilai chi-square tidak terpenuhi. Disajikan pada Tabel 4, hal ini dilihat dari nilai chi-square yang memiliki kriterianya diharapkan kecil atau mendekati 0. Hasil pengolahan data dari penelitian ini menunujukkan nilai indikatornya adalah 1881.867 sehingga kesimpulan nya adalah bahwa model ini tergolong poor fit. Nilai $\mathrm{p}$ memiliki kriteria $>0,05$ sedangkan nilai indikatornya adalah 0,000. Kesimpulan yang dapat diketahui bahwa model ini tergolong poor fit. Nilai RSMEA mempunyai kriteria $<0,10$ dan setelah dilakukan pengolahan data nilainya 0,095 sehingga tergolong dalam goodness of fit. Nilai NFI, TLI dan CFI kriterianya adalah > 0,90 nilai, sedangkan nilai indikator yang didapat untuk NFI bernilai 0,643 yang tergolong poor fit. Nilai indikator yang didapat untuk TLI bernilai 0,714 sehingga tergolong poor fit. Nilai indikator yang dihasilkan untuk nilai CFI adalah 0,732 sehingga tergolong poor fit. Nilai CMIN/DF kriterianya adalah batas bawah 1 dan batas atas 5. Nilai indikator yang didapatkan adalah 2,860 sehingga dapat kesimpulannya bahwa model tersebut tergolong goodness of fit. Jadi, pendekatan yang telah dilakukan setelah pengolahan data diketahui lebih banyak indikator yang tergolong goodness of fit yaitu ada empat yang berarti lebih satu. Maka, struktural model yang telah ditentukan layak untuk untuk pengujian hipotesis selanjutnya. 
Tabel 6. Hasil Uji Hipotesis Direct

\begin{tabular}{|c|c|c|c|c|}
\hline Hipotesis & Estimasi & t-value & p-value & Keputusan \\
\hline $\begin{aligned} \mathrm{H}_{1}: \text { Corporate social responsibility } \rightarrow & \text { Customer loyalty }\end{aligned}$ & -0.103 & -0.441 & 0.660 & Tidak Didukung \\
\hline $\begin{array}{l}\mathrm{H}_{2} \text { : Corporate Social Responsibility } \rightarrow \\
\quad \text { Electronic Service Quality }\end{array}$ & 0.732 & 6.707 & 0.000 & Didukung \\
\hline $\mathrm{H}_{3}:$ Corporate Social Responsibility $\rightarrow$ Trust & 0.889 & 7.7231 & 0.000 & Didukung \\
\hline $\begin{array}{l}\mathrm{H}_{4}: \text { Corporate Social Responsibility } \rightarrow \\
\quad \text { Customer Satisfaction }\end{array}$ & 0.776 & 6.860 & 0.000 & Didukung \\
\hline $\begin{array}{l}\mathrm{H}_{5} \text { : Electronic service quality } \rightarrow \\
\quad \text { Customer loyalty }\end{array}$ & 0.008 & 0.071 & 0.943 & Tidak Didukung \\
\hline $\mathrm{H}_{6}:$ Trust $\rightarrow$ Customer loyalty & 0.244 & 1.269 & 0.204 & Tidak Didukung \\
\hline $\mathrm{H}_{7}:$ Customer Satifaction $\rightarrow$ Customer Loyalty & 0.694 & 6.891 & 0.000 & Didukung \\
\hline
\end{tabular}

Pada hasil pengujian hipotesis bahwa hipotesis 1 ini mendukung hasil penelitian sebelumnya yang dilakukan oleh (Raza et al., 2020). Berdasarkan hasil hipotesis pertama berarti adanya keraguan bahwa nasabah akan secara otomatis akan memperhatikan CSR pada saat membuat keputusan pengeluaran dan konsumsi. Hal ini sejalan dengan penelitian yang telah dilakukan oleh (Suminto \& Maharani, 2020) sebelumnya, CSR tidak berpengaruh signifikan terhadap loyalty karena adanya regulasi keharusan perusahaan untuk melakukan kegiatan CSR yang tertuang di UU Perseroan Terbatas. Sehingga pelanggan layanan perbankan berasumsi kegiatan CSR merupakan keharusan dan bukan suatu hal ekstra yang bisa menarik loyalitas. Hipotesis 2 pada penelitian ini didukung yang berarti mendukung hasil penelitian sebelumnya yang dilakukan oleh (Raza et al., 2020) yang menyatakan bahwa adanya pengaruh positif antara CSR terhadap electronic service quality yang berarti semakin besar bank melakukan CSR akan semakin besar pula bank meningkatkan electronic service quality.

Hipotesis 3 ini didukung yang berarti mendukung hasil penelitian sebelumnya yang dilakukan oleh (Glaveli, 2020) yang menyatakan bahwa adanya pengaruh positif antara CSR terhadap trust, hal ini menunjukkan bahwa tindakan CSR terhadap karyawan dan masyarakat atau lingkungan cenderung merangsang trust pada konsumen. Kontribusi sosial kemasyarakatan ini juga yang membuat pelanggan layanan perbankan dapat melihat pertukaran sosial antara perusahaan dengan masyarakat. Hal inilah yang menimbulkan kepercayaan serta rasa kepuasan dari pelanggan terhadap bisnis yang dilakukan oleh perusahaan perbankan dan ingin terus menggunakan layanannya. Hasil dari penelitian yang hipotesis 4 yang telah dilakukan menunjukan bahwa terdapat adanya pengaruh antara CSR terhadap customer satisfaction yang mendukung hasil penelitian sebelumnya yang dilakukan oleh (Akbari et al., 2019) yang menyatakan bahwa adanya pengaruh positif antara CSR terhadap customer satisfaction yang berarti terlibat dalam CSR dapat membantu perbankan untuk memahami nasabah lebih baik dan akibatnya bank memiliki pengetahuan khusus yang lebih detail mengenai para nasabahnya. 
Tabel 7. Hasil Uji Hipotesis Indirect

\begin{tabular}{|c|c|c|c|c|c|}
\hline Hipotesis & Model & Estimate & t-value & P-value & Kesimpulan \\
\hline \multirow{7}{*}{$\mathrm{H}_{8}$} & Model 1 & & & & \\
\hline & $\begin{array}{l}\text { Terdapat pengaruh corporate social } \\
\text { responsibility } \rightarrow \text { customer loyalty } \\
\text { Model } 2\end{array}$ & 0.516 & 6.134 & 0.000 & Didukung \\
\hline & $\begin{array}{l}\text { Terdapat pengaruh corporate social } \\
\text { responsibility } \rightarrow \text { electronic service }\end{array}$ & 0.591 & 6.835 & 0.000 & Didukung \\
\hline & quality & & & & \\
\hline & $\begin{array}{l}\text { Terdapat pengaruh electronic service } \\
\text { quality } \rightarrow \text { customer loyalty }\end{array}$ & 0.345 & 2.623 & 0.009 & Didukung \\
\hline & $\begin{array}{l}\text { Terdapat pengaruh corporate social } \\
\text { responsibility } \rightarrow \text { customer loyalty }\end{array}$ & 0.338 & 3.155 & 0.002 & $\begin{array}{l}\text { Didukung } \\
\text { (Parsial } \\
\text { Mediasi) }\end{array}$ \\
\hline & $\begin{array}{l}\text { Model } 1 \\
\text { Terdapat } \rightarrow \text { corporate social } \\
\text { responsibility terhadap customer loyalty } \\
\text { Model } 2\end{array}$ & 0.516 & 6.134 & 0.000 & Didukung \\
\hline \multirow{3}{*}{$\mathrm{H}_{9}$} & $\begin{array}{l}\text { Terdapat pengaruh corporate social } \\
\text { responsibility } \rightarrow \text { trust }\end{array}$ & 0.740 & 7.416 & 0.000 & Didukung \\
\hline & $\begin{array}{l}\text { Terdapat pengaruh trust } \rightarrow \text { customer } \\
\text { loyalty }\end{array}$ & 0.474 & 2.531 & 0.011 & Didukung \\
\hline & $\begin{array}{l}\text { Terdapat pengaruh corporate social } \\
\text { responsibility } \rightarrow \text { customer loyalty }\end{array}$ & 0.199 & 1.298 & 0.194 & $\begin{array}{l}\text { Tidak } \\
\text { Didukung } \\
\text { (Full } \\
\text { Mediasi) }\end{array}$ \\
\hline \multirow{4}{*}{$\mathrm{H}_{10}$} & $\begin{array}{l}\text { Model } 1 \\
\text { Terdapat pengaruh corporate social } \\
\text { responsibility } \rightarrow \text { customer loyalty } \\
\text { Model } 2\end{array}$ & 0.516 & 6.134 & 0.000 & Didukung \\
\hline & $\begin{array}{l}\text { Terdapat pengaruh corporate social } \\
\text { responsibility } \rightarrow \text { customer satisfaction }\end{array}$ & 0.711 & 7.334 & 0.000 & Didukung \\
\hline & $\begin{array}{l}\text { Terdapat pengaruh customer } \\
\text { satisfaction } \rightarrow \text { customer loyalty }\end{array}$ & 0.620 & 7.475 & 0.000 & Didukung \\
\hline & $\begin{array}{l}\text { Terdapat pengaruh corporate social } \\
\text { responsibility } \rightarrow \text { customer loyalty }\end{array}$ & 0.095 & 1.515 & 0.130 & $\begin{array}{l}\text { Tidak } \\
\text { Didukung } \\
\text { (Full } \\
\text { Mediasi) }\end{array}$ \\
\hline
\end{tabular}

Hipotesis 5 pada penelitian ini tidak didukung yang menunjukan bahwa tidak terdapat pengaruh signifikan antara electronic service quality terhadap customer loyalty yang berarti tidak sejalan dengan penelitian (Raza et al., 2020). Hasil ini ternyata sejalan dengan apa yang dikemukakan oleh (Berliana \& Zulestiana, 2020). Hal ini dapat diartikan bahwa pelanggan lebih sensitif terhadap aktifitas marketing seperti promo dan lainnya yang dilakukan oleh perusahaan daripada ESQ yang perusahaan miliki. Alasan lainnya juga karena electronic service quality saat ini sudah menjadi sesuatu yang umum dan perbankan sudah wajib memberikan fasilitas tersebut yang bukan lagi menjadi sesuatu yang istimewa. Hipotesis 6 pada penelitian ini menguji pengaruh trust terhadap customer loyalty. Hasil dari penelitian yang telah dilakukan menunjukan bahwa tidak terdapat pengaruh signifikan antara trust terhadap customer loyalty berarti hasil penelitian ini tidak sejalan dengan penelitian (Ashraf et al., 2017). Berdasarkan penelitian ini berarti trust ini sudah diwajibkan oleh OJK sebagai regulator perbankan untuk setiap perbankan dapat mengelola keuangan nasabah dengan baik. 
Hasil penelitian hipotesis 7 didukung yang berarti mendukung hasil penelitian sebelumnya yang dilakukan oleh (Akbari et al., 2019) yang menyatakan bahwa adanya pengaruh positif pengaruh customer satifaction terhadap customer loyalty yang berarti kualitas pelayanan adalah factor utama customer satisfaction yang menjadi prediktor terciptanya customer loyalty. Kepuasan dari pelangganlah yang menjadi kunci dan katalis penting agar pelanggan setia untuk tetap menggunakan jasa perusahaan. Hasil hipotesis 8 ini didukung yang berarti $C S R$ berpengaruh terhadap customer loyalty ketika dimediasi oleh electronic service quality mendukung penelitian sebelumnya yaitu (Raza et al., 2020) yang berarti jika bank melakukan CSR maka nasabah akan secara positif mengevaluasi kualitas layanan secara keseluruhan. Ketika pelanggan memiliki persepsi positif terhadap electronic service quality, maka evaluasi layanan elektronik ini berdampak positif terhadap customer loyalty. Hasil hipotesis 9 ini didukung, berarti CSR berpengaruh terhadap customer loyalty ketika dimediasi oleh trust. Hasil penelitian ini mendukung penelitian sebelumnya yaitu (Raza et al., 2020) yang berarti CSR yang digerakkan oleh laba perusahaan dapat merusak reputasi perusahaan yang menegaskan bahwa untuk mencapai customer loyalty dan reputasi yang baik, perusahaan harus mendapatkan trust pelanggan melalui kompetensi, kebajikan, serta kepedulian yang tulus terhadap keberlanjutan bisnis dan sosial kemasyarakatan. Hasil dari hipotesis 10 ini didukung atau CSR berpengaruh terhadap customer loyalty ketika dimediasi oleh customer satisfaction. Hasil penelitian ini mendukung penelitian sebelumnya yaitu (Lee \& Shin, 2018) yang berarti nasabah cenderung lebih puas dengan produk dan layanan yang ditawarkan oleh perbankan yang bertanggung jawab kepada sosial kemasyarakatan dengan aktivitas CSR.

\section{SIMPULAN DAN REKOMENDASI}

Penelitian yang telah dilakukan ini menunjukkan hasil bahwa CSR tidak memiliki pengaruh positif secara langsung pada loyalitas konsumen. Variabel lain seperti electronic service quality dan trust memiliki pengaruh terhadap customer loyalty, namun tidak signifikan. Sedangkan customer satisfaction secara langsung mempunyai pengaruh positif terhadap loyalitas. Hasil yang diperoleh dari penelitian ini menunjukkan bahwa CSR yang dimediasi oleh electronic service quality, trust, dan customer satisfaction masing - masing secara keseluruhan memliki pengaruh positif terhadap loyalitas nasabah bank di Indonesia. Sehingga bisa diketahui bahwa untuk mendapatkan loyalitas nasabah, perbankan tidak hanya bisa bergantung dengan aktivitas CSR sendiri, namun harus dimaksimalkan dengan variabel penunjang lainnya seperti ESQ, trust, customer satisfaction dan variabel lain yang tidak diteliti dalam penelitian ini.

Penelitian yang ini memiliki implikasi teoritis tentang CSR perusahaan dan loyalitas konsumen. Dari sudut pandang teori, penelitian ini menjadi penelitian pertama yang menggabungkan CSR, electronic service quality, trust, customer satisfaction, dan customer loyalty dalam satu model. Penelitian ini memperkenalkan pola baru dari electronic service quality, trust, dan customer satisfaction dimana secara keseluruhan berperan dalam membentuk loyalitas konsumen.

Implikasi manajerial yang bisa ambil dari penelitian ini adalah untuk mendapatkan loyalitas yang nasabah, perusahaan perbankan harus bisa mencapai customer satisfaction. Karena kepuasan nasabah berdampak signifikan kepada kesetiaannya menggunakan layanan perbankan di mana semakin banyak bank yang beroperasi di Indonesia dengan produk dan manfaat yang kurang lebih sama. Manajer perbankan harus bisa mengoptimalkan kegiatan CSR yang digunakan dengan 
peningkatan ESQ serta trust nasabah untuk mendapatkan loyalitas nasabah. Kegiatan-kegiatan sosial kemasyarakatan yang berorientasi kepada keberlanjutan menjadi salah satu opsi terbaik yang bisa digunakan oleh perbankan dalam pengoptimalisasian aktivitas CSRnya.

Keterbatasan yang dimiliki dalam penelitian yang telah dilakukan ini diantaranya yaitu, bersifat spesifik meneliti nasabah bank di Indonesia dengan kategori buku 4 (empat). Penelitian ini hanya meneliti pengaruh hubungan variabel CSR terhadap customer loyalty baik secara langsung dan juga melalui mediasi electronic service quality, trust, dan customer satiscaftion. Menggunakan sampel dari nasabah perorangan tidak melibatkan nasabah korporasi maupun lembaga.

Saran dari hasil penelitian ini, untuk penelitian selanjutnya dapat melibatkan nasabah bank-bank diluar buku 4 (empat), kemudian penelitian selanjutnya dapat menambahkan variabel yang relevan seperti corporate image (Chang \& Yeh, 2017), serta peneliti selanjutnya dapat dilakukan pada perusahaan selain perbankan dan melibatkan sampel nasabah korporasi maupun lembaga, tidak hanya nasabah peorangan. Variabel-variabel lain yang dapat dimasukkan dalam pengembangan penelitian berikutnya antara lain customer experience, customer engagement, value co-creation, commitment, service innovation, credibility, dan perceived service quality. Penelitian setelah ini dapat menggunakan model-model penelitian yang lain, termasuk piramida CSR Carol yang menggunakan tiga prinsip dasar yaitu Profit, People, Planet (3P).

\section{DAFTAR PUSTAKA}

Akbari, M., Mehrali, M., SeyyedAmiri, N., Rezaei, N., \& Pourjam, A. (2019). Corporate social responsibility, customer loyalty and brand positioning. Social Responsibility Journal, 16(5), 671-689.

Aksar, M., Kayani, M., \& Ali, M. (2019). A study of customer satisfaction and customer loyalty in the restaurant and hotel industry of Pakistan. Global Journal of Environmental Sciences, I(2), 137-151.

Amin, M. (2016). Internet banking service quality and its implication on e-customer satisfaction and e-customer loyalty. International Journal of Bank Marketing, 34(1), 1-5.

Ashraf, S., Ilyas, R., Imtiaz, M., \& Tahir, H. M. (2017). Impact of CSR on Customer Loyalty: Putting Customer Trust, Customer Identification, Customer Satisfaction and Customer Commitment into Equation-A study on the Banking Sector of Pakistan. International Journal of Multidisciplinary and Current Research, 5(Nov/Dec), 1362-1372.

Berliana, M., \& Zulestiana, D. A. (2020). Pengaruh E-Service Quality terhadap Customer Satisfaction dan Loyalty pada Pengguna Gopay di Indonesia. REMIK (Riset Dan E-Jurnal Manajemen Informatika Komputer), 4(2), 11-17.

Chairy, V. W. D. (2019). Pengaruh Service Environment, Customer Knowledge, Dan Customer Relation Management Terhadap Service Quality Dan Dampaknya Terhadap Brand Equity. Jurnal Manajemen Bisnis Dan Kewirausahaan, 3(2), 1-14.

Chang, Y. H., \& Yeh, C. H. (2017). Corporate social responsibility and customer loyalty in intercity bus services. Transport Policy, 59(October 2016), 38-45.

Faqihudin, A. (2020). Pengaruh Penerapan Corporate Social Responsibility (CSR), Corporate Image, dan Keputusan Nasabah terhadap Loyalitas Nasabah. Jurnal Akuntansi \& Keuangan Daerah, 15(1), 67-76. 
Farooq, M. S., \& Salam, M. (2020). Nexus between CSR and DSIW: A PLS-SEM Approach. International Journal of Hospitality Management, 86(May 2019), 1-21.

Glaveli, N. (2020). Corporate social responsibility toward stakeholders and customer loyalty: investigating the roles of trust and customer identification with the company. Social Responsibility Journal, 17/3(2019), 367-383.

Islam, T., Islam, R., Pitafi, A. H., Xiaobei, L., Rehmani, M., Irfan, M., \& Mubarak, M. S. (2021). The impact of corporate social responsibility on customer loyalty: The mediating role of corporate reputation, customer satisfaction, and trust. Sustainable Production and Consumption, 25, 123-135.

Jeon, M. M., Lee, S., \& Jeong, M. (2020). Perceived corporate social responsibility and customers' behaviors in the ridesharing service industry. International Journal of Hospitality Management, 84(2018), 1-10.

Jonathan, H. (2013). Analisis Pengaruh E-Service Quality terhadap Customer Satisfaction yang Berdampak pada Customer Loyalty PT Bayu Buana Travel Tbk. The Winners, 14(2), 104112.

Lee, I., \& Shin, Y. J. (2018). Fintech: Ecosystem, business models, investment decisions, and challenges. Business Horizons, 61(1), 35-46.

Mariño-Romero, J. M., Hernández-Mogollón, J. M., Campón-Cerro, A. M., \& Folgado-Fernández, J. A. (2020). Corporate social responsibility in hotels: A proposal of a measurement of its performance through marketing variables. Sustainability (Switzerland), 12(7), 1-15.

Nasution, S., Siregar, H., \& Novianti, T. (2020). Efficiency Analysis of Bank Bumn Buku Empat and Its Determinant in Indonesia. Jurnal Aplikasi Manajemen, 18(1), 95-104.

Nguyen, X. H., Tran, H. L., Phan, H. A., \& Phan, T. T. H. (2020). Factors influencing customer satisfaction: The case of facebook chabot vietnam. International Journal of Data and Network Science, 4(2), 167-178.

Nisa, C. (2018). Evaluasi Efisiensi Perbankan Di Indonesia Berdasarkan Kategori Jumlah Modal Inti. JBMI (Jurnal Bisnis, Manajemen, Dan Informatika), 15(2), 101-120.

Nurul, H. (2021). Daftar Bank BUKU 4 di Indonesia [Modal Inti Rp30 Triliun]. In Lifepal (p. 1). https://lifepal.co.id/media/bank-buku-4/

Osakwe, C. N., \& Yusuf, T. O. (2020). CSR: a roadmap towards customer loyalty. Total Quality Management \& Business Excellence, 17(February), 1-17.

Park, J., Lee, H., \& Kim, C. (2014). Corporate social responsibilities, consumer trust and corporate reputation: South Korean consumers' perspectives. Journal of Business Research, 67(3), 295-302.

Paulík, J., Kombo, F., \& Ključnikov, A. (2015). CSR as a driver of satisfaction and loyalty in commercial banks in the Czech republic. Journal of International Studies, 8(3), 112-127.

Pérez, A., \& del Bosque, I. R. (2015). Corporate social responsibility and customer loyalty: Exploring the role of identification, Satisfaction and type of company. Journal of Services Marketing, 29(1), 15-24.

Prieto, A. B. T., Shin, H. K., Lee, Y., \& Lee, C. W. (2020). Relationship among CSR initiatives and financial and non-financial corporate performance in the ecuadorian banking environment. Sustainability (Switzerland), 12(4), 1-16. 
Prisanti, M. Della, Suyadi, I., \& Arifin, Z. (2017). Pengaruh E-Service Quality dan E-Trust terhadap E-Customer Satisfaction serta Implikasinya terhadap E-Customer Loyalty. Journal of Business Studies, 2(1), 19-38.

Rahahleh, A., Al-Nsour, S., Moflih, M., Alabaddi, Z., Al-Nassar, B., \& Al-Nsour, N. (2020). The influence of electronic service quality on relationship quality: Evidence from tourism industry. Management Science Letters, 10(12), 2759-2768.

Rasheed, H. M. W., Khalid, J., Khizar, H. M. U., Sajid, M., Shahid, M. N., Ahmad, M., \& Khan, W. A. (2015). Factors affecting Customer Loyalty in Banking Sector: A study on Banks in Bahawalpur (Pakistan). International Journal of Accounting and Financial Reporting, 5(1), 239-254.

Rastini, N. M., \& Nurcaya, N. (2019). Customers trust mediation: effect of CSR and service quality towards e-WOM. International Research Journal of Management, IT and Social Sciences, 6(4), 169-173.

Raza, A., Rather, R. A., Iqbal, M. K., \& Bhutta, U. S. (2020). An assessment of corporate social responsibility on customer company identification and loyalty in banking industry: a PLSSEM analysis. Management Research Review, 43(11), 1337-1370.

Safi, F. O. D, \& Alagha, M. S. (2020). The Relationship Between Service Quality And Customer Satisfaction. International Journal of Scientific and Research Publications (IJSRP), 10(8), 767-787.

Sanaullah, A. (2018). The Impact of Relationship Benefits on Cistomer Loyalty in Service Firms. Pakistan Business Review. 20, 239-253.

Sari, N. K., \& Widaninggar, N. (2018). Efisiensi Bank dalam Kelompok BUKU 4 di Indonesia: Pendekatan Data Envelopment Analysis. AFRE (Accounting and Financial Review), 1(2).

Sari, Y. K. (2018). Pengaruh Kualitas Pelayanan, Relationship Marketing dan Corporate Social Responsibility terhadap Loyalitas dan Kepuasan Nasabah. Jurnal Bisnis Dan Manajemen, $17(2), 1-14$.

Sekaran, U., \& Bougie, R. (2016). Research Methods for Business: A skill Building Approach. New York: John Wileys \& Sons.

Setiantono et al, E. (2020). Pengaruh strategi implementasi corporate social responsibility terhadap trust masyarakat, dan komitmen perusahaan serta dampaknya pada kinerja perusahaan. Jurnal Ekbang, 3(1), 1-16.

Shah, S. S. A., \& Khan, Z. (2019). Corporate social responsibility: a pathway to sustainable competitive advantage? International Journal of Bank Marketing, 38(1), 159-174.

Shankar, A., \& Jebarajakirthy, C. (2019). The influence of e-banking service quality on customer loyalty: A moderated mediation approach. International Journal of Bank Marketing, 37(5), 1119-1142.

Smith, T. A. (2020). The role of customer personality in satisfaction, attitude-to-brand and loyalty in mobile services. Spanish Journal of Marketing - ESIC, 24(2), 155-175.

Suminto, A., \& Maharani, S. (2020). Analisis Pengaruh Corporate Social Responsbility, Islamic Banking Service Quality dan Corporate Image terhadap Loyalitas Nasabah di Bank BRISyariah Kantor Cabang Pembantu Ponorogo. El-Barka: Journal of Islamic Economics and Business, 3(1), 51-79. 